\title{
A LIST OF DRAGON-FLIES COLLECTED AT WAREHAM, MASS., DURING THE YEARS 1911 TO 1913 BY MR. OUTRAM BANGS.
}

By R. Heber Howe, JR.

Thoreau Museum of Natural History, Concord, Mass.

The following rather remarkable list of Odonata is the result of my determination of a collection made by Mr. Bangs at Wareham, Massachusetts, and the material on which it is based is now distributed through the general collection of the Museum of Comparative Zoölogy, Cambridge, Mass. Access to the specimens was obtained through the kindness of Mr. Nathan Banks, and permission to publish the list secured from both Mr. Banks and Dr. Samuel Henshaw. Several duplicates are in the author's collection, and that of the Boston Society of Natural History.

Though Mr. Bangs is not familiar with the group Odonata his trained naturalist's eye made it possible for him to collect a very large percentage of the species that occur, and the list is deficient only in the Zygoptera or smaller Damsel-flies. Mr. Bangs has provided annotations of several interesting species.

\section{Zygoptera.}

1. Agrion cequabile (Say). "Occurs only, so far as I know, along Eagle hill river. I got one."

2. Agrion maculatum Beauv. June 2-9. Several specimens.

3. Lestes eurinus Say. June to July 30. Several specimens.

4. Lestes unguiculatus Hagen. One specimen.

5. Lestes rectangularis (Say). June 28 to July 30 . Several specimens. I collected it at Monument Beach.

6. Lestes vigilax Hagen. July 30. One specimen. I collected it at Wareham in 1917.

7. Lestes inequalis Walsh. Aug. 12. One specimen.

Note: I collected Lestes forcipatus Rambur., in the nearby town of Monument Beach.

8. Argia violacea (Hagen). July 5 to Sept. 4. Several specimens. I collected it at Wareham in 1917.

9. Enallagma durum (Hagen) June to Aug. 3. Several specimens. This is the most northern station for this species. 
10. Enallagma traviatum Selys. July 8. One specimen.

11. Enallagma civile (Hagen). I collected this species at Wareham in 1917, and Mr. Bangs has one doubtful specimen in his collection.

12. Enallagma pictum Morse. July 8 to 30 . Two specimens. This is the second New England record for this species, and the most northern station for it.

13. Enallagma signatum (Hagen). Aug. 3. One specimen.

14. Amphiagrion saucium (Burm.). Aug. 3. Several specimens.

15. Ischnura verticalis (Say). June to July 10. Several specimens. I collected the species at Monument Beach in 1917 .

16. Anomalagrion hastatum (Say). July 10. Several specimens.

\section{Anisoptera.}

17. Cordulagaster diastatops Selys. June 17. One specimen.

18. Progomphus obscurus Ramb. July 5 to 29 . Several specimens. Not uncommon in the oak scrub Mr. Bangs tells me. This is the second New England Station for this species.

19. Hagenius brevistylus Selys. July 8. "Local, usually seen along cranberry bog ditches and brooks." This is the most southern latitudinal record for the species.

20. Gomphus exilis Selys. July 5 to 8 . Two specimens.

21. Dromogomphus spinosus Selys. July 29 to Sept. 1. Several specimens.

22. Boyeria vinosa (Say). June to Aug. 15. Two specimens.

23. Basiaschna janata (Say). May 31. One specimen.

24. Anax junius (Drury). June 17 to Sept. 20. Several specimens

25. Anax longipes Hagen. "Seen three or four times always over ponds. Hard to catch." Mr. Bangs is sure that his determination is correct. This is the second New England station for the species.

26. AEshna canadensis Walk. Aug. 16 to 20. Several specimens.

27. Eshna clepsydra Say. Aug. 7. One specimen.

28. AEshna umbrosa Walk. Aug. 23 to Sept. 11. Several specimens.

29. Epiaschna heros (Fabr.). Sept. 20. One specimen.

30. Macromia illinoiensis Walsh. July 27. One specimen. 
31. Epicordulia princeps (Hagen). July 3 to 26 . "Common at times."

32. Tetragoneuria cynosura (Say). May 3 to Aug. 3. Several specimens.

33. Tetragoneuria cynosura simulans Mutt. May 3 to July 9. Several specimens.

34. Dorocordulia lepida (Hagen). June 28 to Aug. 3. Several specimens.

35. Somatochlora tenebrosa (Say). Aug. 2 to \%. Several specimens. 36. Libellula (Ladona) exusta Say. May 7 to July 9. Several specimens.

37. Libellula auripennis Burm. July 4 to 30. Several specimens. 38. Libellula cyanea Fabr. June 28 to Aug. 7. Several specimens. The females of the series approach very closely L. flavida Will.

39. Libellula incesta Hagen. July 6 to Aug. 5. Several specimens. One specimen shows a slight approach to $L$. flavida Williamson in the number of subtriangle cells.

40. Libellula pulchella Drury. June 20 to Aug. 8. Several specimens.

41. Libellula quadrimaculata Linn. May 31 to June 28. Several specimens.

42. Libellula semifasciata Burm. May 3 to Aug. 7. Several specimens.

43. Plathemis lydia (Drury). May 31 to July 5. Several specimens.

44. Perithemis domitia tenera (Say). July 18 to Aug. 9. Several specimens.

45. Nannothemis bella (Uhler). July 8. Several specimens.

46. Erythrodiplax berenice (Drury). July 8 to 10 . Several specimens. Confined to salt marshes.

47. Erythemis simplicicollis (Say). July 8 to 30 . Several specimens.

48. Sympetrum costiferum (Hagen). Aug. 6. One specimen.

49. Sympetrum rubicundulum (Say). June 17 to July 30. Several specimens.

50. Sympetrum semicinctum (Say). July 30 to Aug. 7. Several specimens.

51. Sympetrum vicinum (Hagen). June. One specimen. 
52. Pachydiplax longipennis (Burm.). June 7 to Aug. 6. Several specimens.

53. Leucorrhinia frigida Hagen. June to Aug. 11. Several specimens. This is the most southern station for this northern species.

54. Leucorrhinia intacta Hagen. June 9. Several specimens.

55. Celithemis elisa (Hagen). July 26 to Aug. 11. Several specimens.

56. Celithemis eponina (Drury). July 8 to Aug. 16. Several specimens.

57. Celithemis monomelcana Will. July 8 to Aug. 14. Several specimens. This is the most northern and second New England record and station for this rare southern species.

58. Celithemis ornata Ramb. July 2 to Aug. 14. Several specimens.

59. Pantala flavescens (Fabr.). Aug. 9. One specimen.

60. Tramea carolina (Linn.). June to July 30. Several specimens.

\section{NOTE ON THE GENUS LIOBRACON, WITH THE DESCRIPTION OF A NEW SPECIES (HYMEN- OPTERA; BRACONIDE).}

\section{By Charles T. Brues,}

Bussey Institution, Harvard University.

In a small collection of Parasitic Hymenoptera collected in Hayti several years ago by Dr. William M. Mann, I have found several specimens of the insect described by Cresson as Bracon distinctus in his "Hymenoptera of Cuba." This proves to belong to the genus Liobracon Szépligeti, to which several South American species have hitherto been referred. In addition there is a second species taken by Dr. Mann which is described below.

\section{Liobracon Szépligeti.}

Termes Füzetek, Vol. 24, p. 361. (1901.)

Gen. Ins., fasc. 22, p. 66 . (1904.)

Type L. macula Brullé (singularis Szép).

The species may be distinguished as follows: 

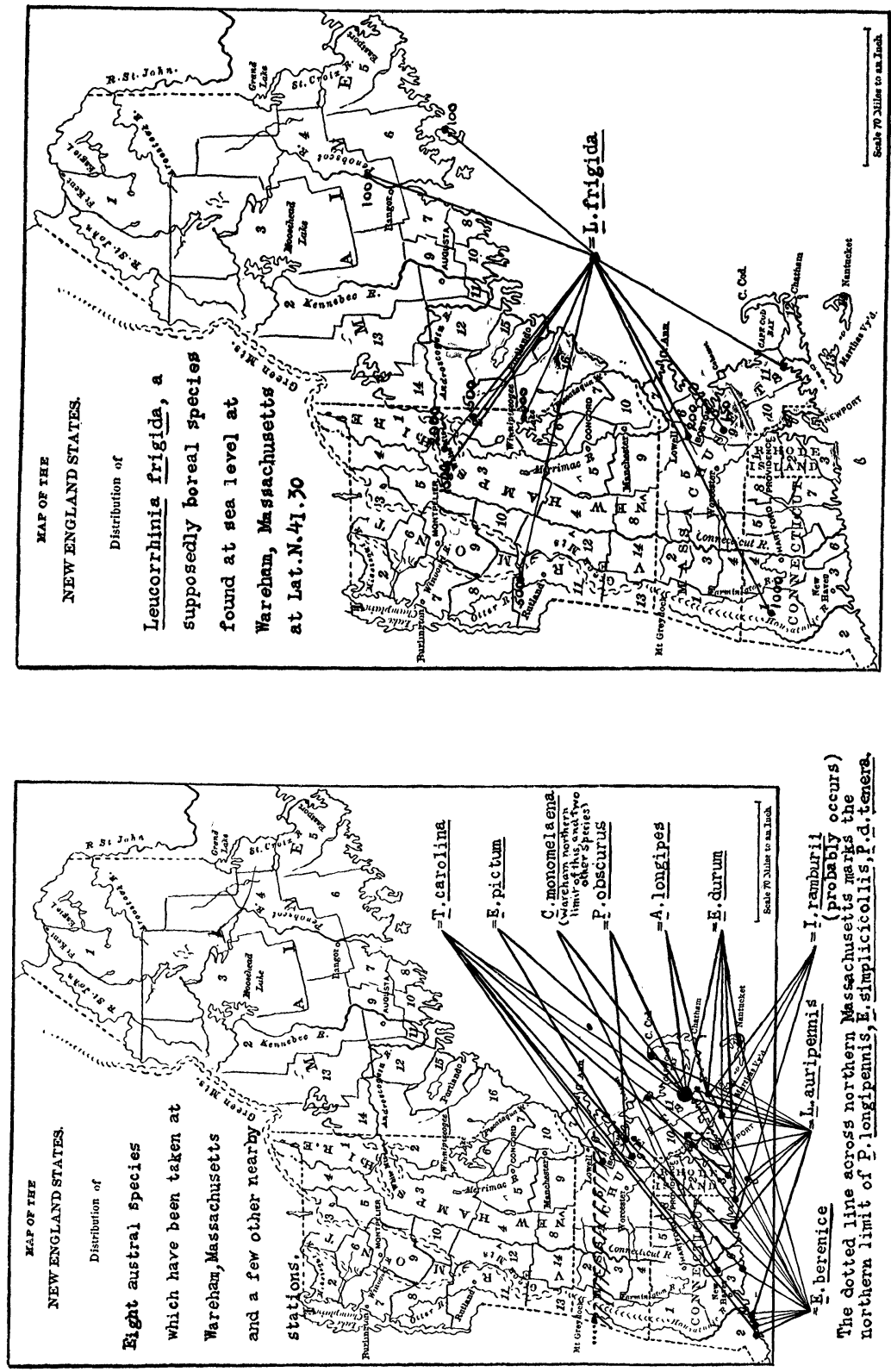

Howe-Dragon-Flies from Wareham, Mass. 

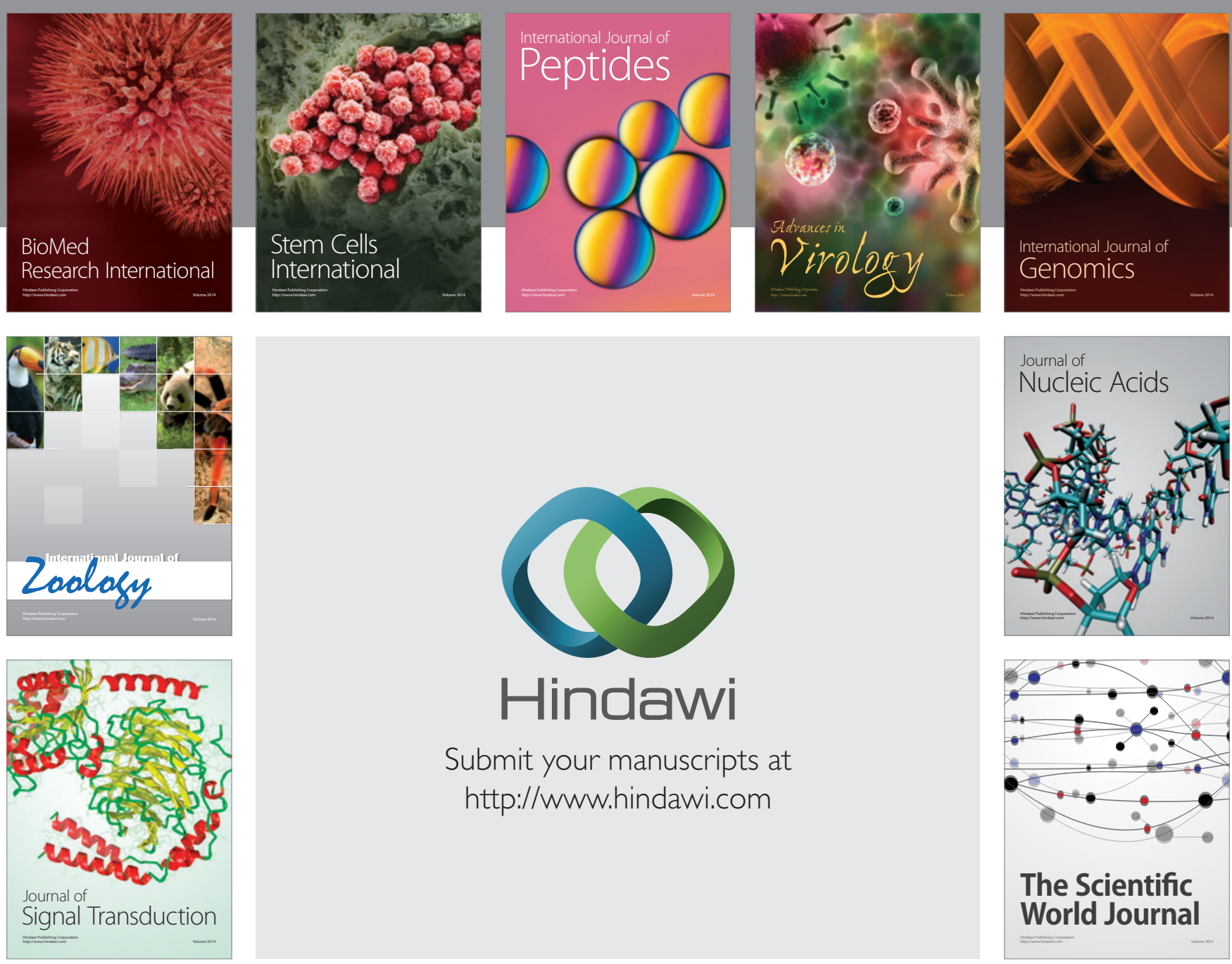

Submit your manuscripts at

http://www.hindawi.com
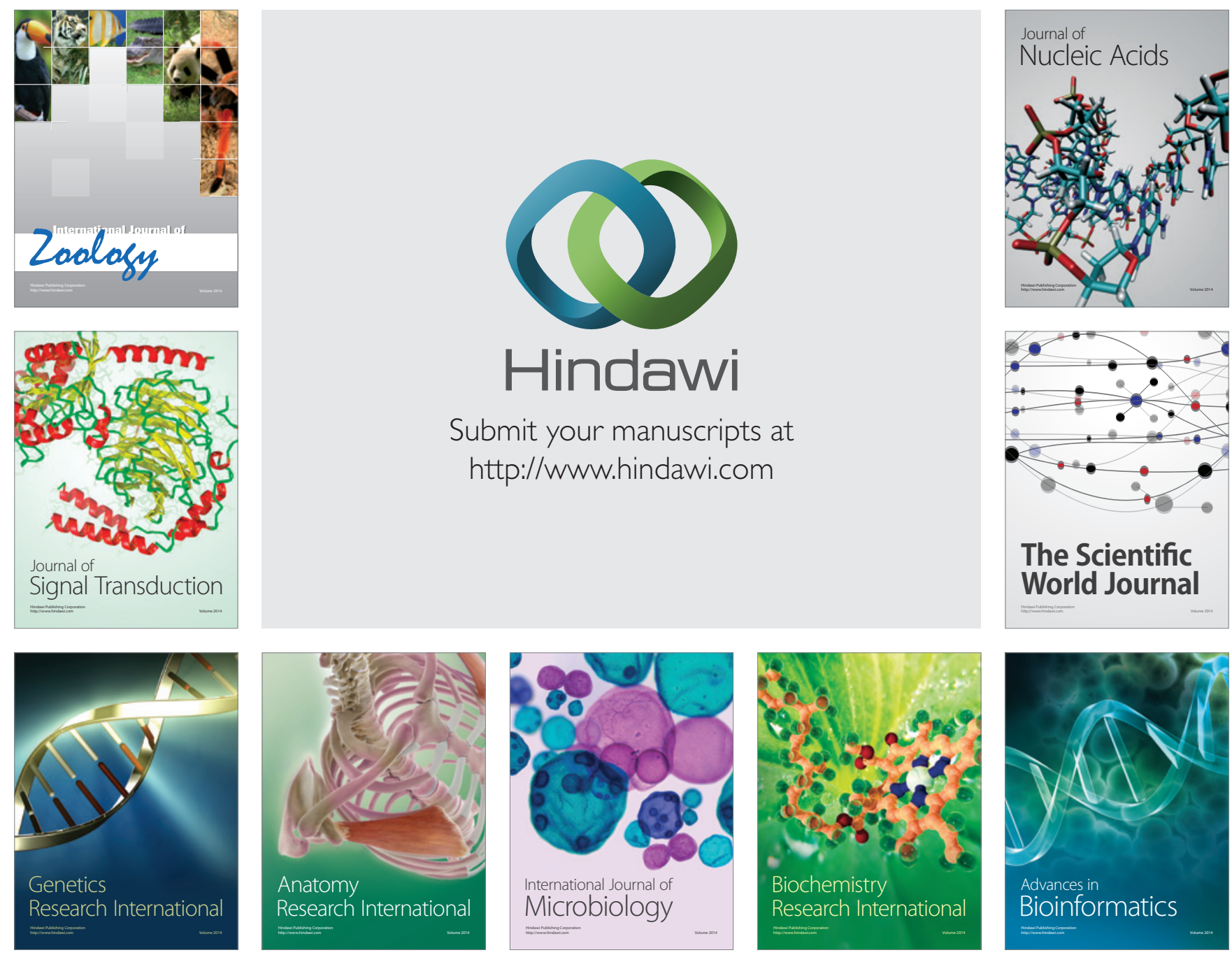

The Scientific World Journal
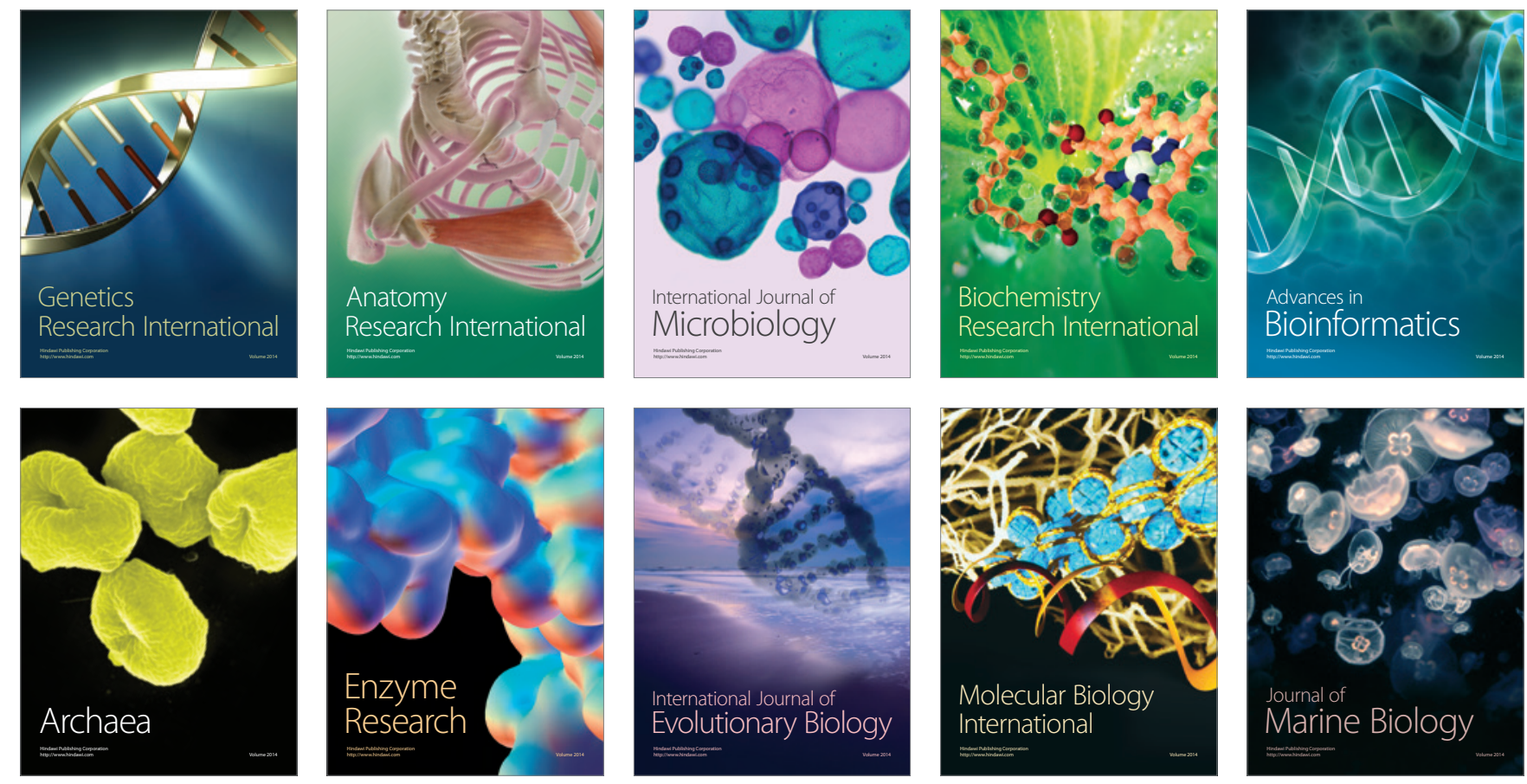